\title{
TURKEY'S MULTI-POLAR DIPLOMACY ON ITS WAY TO THE EUROPEAN UNION
}

\author{
LIKA MKRTCHYAN \\ lika.mkrtchyan@gmail.com
}

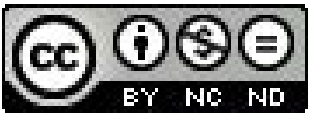

\begin{abstract}
Turkey conducts a multi-polar foreign diplomacy in order to strengthen its positions in the region, to gain control over the neighboring countries; as well as to make its way towards the European Union. Being on the EU's waiting list, Turkey strives to get advantages of its prolonged status as a candidate country.
\end{abstract}

Key words: Turkey, European Union, role in the Caucasus, partnership, home and foreign Policy

\section{TURKEY-EU RELATIONS}

Perhaps one of the most complicated challenges that the European Union has faced during its existence in the fields of enlargement and foreign policy is the relations with Turkey. Being Europe's "thorny" issue, Turkey has been striving to enter the European family since 1963, when, on September 12, Ankara signed an agreement to become an associate member of the predecessor of the European Union the European Economic Community - Agreement Creating An Association Between The Republic of Turkey and the European Economic Community, which is known as "Ankara Agreement"; whereas the formal application to join the European Community was submitted on April 14, 1987. However, Turkey's potential accession to the EU was legislatively fixed only in 2000. In 2004 the European Community gave Turkey an accord to start the accession negotiations and the official membership negotiations with EU started on October 3, 2005 (Accession of Turkey to the European Union).

After all the 25 member states reached an agreement, overcoming Austria's oppositions, the membership negotiations with the European Union started by adopting a framework for the candidate country - Turkey. Austria was proposing for Turkey to become a "privileged partner" instead of a "full member", as future full membership demanded/demands various aspects to be committed by Ankara to fulfill the criteria of membership known as "Copenhagen Criteria" (European Council in Copenhagen, June 21-22, 1993, Conclusions of the Presidency). The agreement to grant Turkey a status of a country-negotiator has been reached after a series of pre-negotiations and U.S. intervention.

So what kind of relations do the Union and Turkey have? Most of the powerful members of the EU (France, Netherlands, Austria) openly state their opposition towards the country's accession, at the same time stating that they see a potential economic partner in Turkey. As a matter of fact, Turkey plays an important role not only in the field of trade, but also gas supply. The EU members, especially 
those that border with Russia and Ukraine speak in favor of Turkey's accession to "rely" on the latter's gas supply and get free from the "clutches" of the former two. Turkey itself represents a country of interest judging from its geographical location - not from the viewpoint that it serves a kind of a "bridge" between East and West, as many experts state today, but from the fact that it has access to four seas, and besides, owns a great part of the Black Sea pool.

Apart from economic relations, Europe does not seem to share any common interests with Turkey, moreover, it does not see any profit by welcoming the country into the Union. Putting aside the Copenhagen criteria and any other formal issues that Turkey has to fulfill for becoming a full member of the EU (which is not guaranteed even if all the 35 chapters of the acquis communautaire are completed), the Union has its own fears of getting enlarged by such a complicated region as the Caucasus and its neighborhood.

Perhaps one of the main fears of the Union is that of losing its grip over the region, moreover losing the grip over Europe. Despite the fact that Ankara will significantly expand the interior market of the Union and dispose labor force for European companies which today face the fast aging of population, the problem of demography is of great concern for European super powers.

According to various forecasts, by 2020, being a Muslim country, the population of Turkey will have exceeded the population of any EU country. As of 2008 data, the population of Germany was $81.47 \mathrm{mln}$, and Turkey $78.78 \mathrm{mln}$ (World StatInfo). Taking into account the principle of the current distribution of votes in EU institutions, in the case of accession, Turkey will immediately become one of the most powerful and effective, but at the same time the poorest member of the European Union.

In general, when considering Turkey-EU relations, the following image can be observed: the EU is friendly "smiling" towards its future Eastern counterpart, "welcoming" it open-handedly to join their family, but at the same time it is pushing Turkey back citing the non-correspondence of its foreign and home policy, as well as geographical location. The impression is that they both pursue bilateral profit by "using" each other. Apart from the apparent energy issue Europe's policy towards Turkey evokes certain suspicions of making its way towards the Eastern world by treating Turkey a kind of a "bridge" between East and West.

However, culturally, politically and socially Armenia and Georgia are closer to Europe than Turkey, and actually they represent more of a "bridge" than an Islamic country. Despite visual "privileged partner" relations with Turkey, the EU does not seem to treat the country on an equal level with its other member states, because the word "partner" here refers to the economic, more precisely, trade-energy-gas relations between the EU and Turkey. The latter has got an agreement with Azerbaijan on gas transit to Europe in order to lessen the Russian influence and the continent's dependence from its gas.

\section{THE BENEFITS OF BEING A CANDIDATE COUNTRY}

Another interesting thing about Turkey's candidacy is the benefits that it pursues. It is almost 50 years that Turkey has Euro aspirations, however, it is never 
sure to be accepted into the Union. The country has been trying to change its home and foreign policy, make amendments to its Penal Code, develop democracy, human rights, and provide freedom of speech, in a word make all the EU commitments. It is trying, but perhaps, not very hard, since no significant change has been recorded during recent months. The violence against journalists, national minorities, women and so on testify that the so-called changes have only formal character, which are not executed in practice.

What does it mean? There can be one rational explanation to Turkey's "unserious" policy towards the EU, and the explanation lies in the fact that Turkey pursues another goal. Why should it take so many "efforts" to hit the target, when it is never sure that it may even partially approach it? Undoubtedly, Turkey benefits from being a candidate country, since it receives a certain amount of subsidies and donations from the Union to make its institutions closer to European standards. And under the veil of such standardization it implements another task which is much more important for the country - to strengthen its grip in the region and get power over the Caucasus.

Indirectly, the European Union turns out to be a financial supporter of Turkey's firm base in the Caucasus region. Does it mean that the Union is aware of the double or even triple game that Turkey is playing? If yes, then the policy conducted by Turkey has received Europe's approval, which can be explained by the aim to cut down Russia's influence over the region and gain the status of a powerful unity which moves towards the relative expansion of its borders (for instance, through Eastern partnership) ${ }^{3}$. De facto not accepting these countries into the Union, it offers its support through partnership - for some countries a privileged one. If no, it totally changes the image of the political Europe, thus shifting the main accent towards Turkey, which conducts a multi-polar policy.

If Turkey had no benefits from its status of a candidate, it would have never agreed to go on with the negotiations, especially having no guarantees that one day it may become a full member of the European Union. This fact itself leads to the hypothesis that having no real future expectations, Turkey is happy with its role of a candidate. Having a "pending request" for a several decades, Turkey is promoting its role and positions in the world throwing firm roots into the soil of the region by slowly implementing European commitments through the means received from the Union.

\section{FROM BEING AN EU CANDIDATE COUNTRY TO STRENGTHE- NING POSITIONS IN THE CAUCASUS}

Today Turkey is at the center of the world's attention by conducting a multilateral policy:

\section{Turkey-Iran relations}

A NATO member, Russia's "strategic partner" cooperates with Iran - which speaks against the principles of the Alliance - and conducts joint training with Syria.

This can be compared to the so-called Wilsonian moment in the world order, when America's propaganda tried to hold on "third world" countries in order to keep the Soviet Union in a considerable distance from previously colonized states and other Asian countries 


\section{Turkey-Russia relations}

Turkey is in economic cooperation with Russia, as President Medvedev stated (in 2010) the future establishment of a "large-scale strategic partnership" with Turkey, in particular, dealing with the construction of a nuclear power plant on the Mediterranean, especially with the growing nuclear strength of Iran.

For Turkey it is profitable to have strategic economic relations with Moscow, taking into account that the latter had reached preliminary agreements on getting the right of the NPP construction without a tender in the event of the Russians managing to get the right of its full exploitation.

\section{Turkey-Armenia/Turkey-Cyprus}

In the past two years chances have been granted to Turkey to take up all the opportunities on the international scene. Pretending to be interested in opening the border with Armenia as well as making promises to remove the blockade of air and seaports of Cyprus, Turkey is keeping balance both in the Caucasus region, international relations and its Euro aspirations. The establishment of relations with Armenia as well as opening its closed borders, Turkey was making its way towards the implementation of Copenhagen criteria necessary for the accession into the European Community. Nevertheless, keeping the world in tension for two years, Turkey took a move backward equaling the recent achievements to the ground.

However, the recent developments around Greece and earthquakes open new horizons to Turkey.

a) The strong earthquake in the territory of Van (previously Armenia's territory, acknowledged by Armenians as "Western Armenia") in October 2011 made Turkey officially ask help from Armenia. The Armenian press is being sarcastic about the late-plead for help, quoting Kurdish writer Memed Guler, "Turkey waited until Kurds died under the ruins and only then asked for Armenia's rescue support" (Stepanyan 2011). Political scientists see this, despite the tragedy, as a positive step forward to at last establish diplomatic relations with Turkey.

b) The economic situation of Greece makes most of the EU countries turn their backs towards it. With Germany, and possibly France (depending upon their elections) looking to solidify ties with Russia (due to energy) it could make sense. France and Germany are much stronger on their own without being weighed down by the troubles of the PIIGS (Portugal, Ireland, Italy, Greece, Spain) (Reiermann 2011). Turkey, of course, would have profited from the situation, if Greece were forced out of the Eurozone or European Union, because it would much simplify its accession processes and the problems connected with Cyprus. However, to Turkey's disappointment as well as that of the countries that were speaking in favor of Greece's expulsion, on October 27, 2011, during the overnight emergency summit in Brussels, the European Bank agreed to write off 50 percent of Greek debt and allocate another 1 hundred billion euros until 2014. German Chancellor Angela Merkel and French President Nickolas Sarkozy state that they have excluded the default of Greece. Besides, "Neither exit nor expulsion from 
the euro area is possible, according to the Lisbon treaty under which participation in the euro area is irrevocable," said Amadeu Altafaj, spokesman for EU economic affairs commissioner Olli Rehn.

\section{Turkey-EU}

Despite being busy with its tense and cunning foreign policy and stagnation in accession processes, Turkey goes on with its integration negotiations with the European Parliament. From time to time it manipulates the local and international media by a couple of statements and cases towards the "democratization" of the country, with this maneuvre deflecting the attention of the international society from the real problems and taking the current to the course that it wants to.

\section{Turkey-Azerbaijan}

Finally, Turkey and Azerbaijan, strategic partners for ages that are in brotherly relations blew dust in the eyes of the world by pretending "offense" and discord. Azerbaijan had been threatening with closure of gas pipes and other issues if Turkey goes on supporting the initiative of establishing diplomatic relations with Armenia. Within two years the whole world and international actors have believed that Turkey "had changed" its attitude towards Armenia and started to realize the importance of the open border, especially the economic profit. Meanwhile, Turkey was getting prepared for more important steps to take, such as possessing the reins over the region, as well as to attract Russia's use of the Mediterranean coast, loosen American and French presence in the Caucasus, cooperate with Iran, go on supporting Azerbaijan, thus making its way to Europe.

\section{TURKEY'S STRENGTHENED POSITION UNDERMINES EU INTERESTS IN THE CAUCASUS}

Just at the time of hostilities between Russia and Georgia, Turkey initiated the establishment of the Caucasus Alliance (peoples of the Caucasus joke by calling it the future Caucasus Union) through the Platform for Peace and Security in the Caucasus, which has different interpretations if taking into account the positions of separate countries. According to the analysis of Today's Zaman, Turkey aims to establish permanent peace and security in the Caucasus region with the help of the Alliance, which pursues the goal of uniting the peoples of the region. Turkey believes that it can attain the goal on the basis of the above-mentioned pipelines. As for the Georgian and Armenian analyses, the initiative was interpreted to be taken not for the sake of Abkhazia and South Ossetia, but more for the solution to the conflict between Armenia and Azerbaijan over Nagorno-Karabakh.

However, Georgia has some doubts about Turkey's "devoted" policy, because during the 5-day war it could have expected anything but some sort of betrayal from its "strategic partner," member of NATO who was supporting Georgia with weapons and ammunition. The "betrayal" had its form of expression reflected in the form of a blockade - blocking the way of American ships in the Black Sea, stopping Baku-Tbilisi-Ceyhan and Baku-Tbilisi-Erzrum pipelines a couple of days before the war. 
From the perspective of the Armenian experts, the implementation of the Platform and the Armenian "yes" would mean to yield the territories populated by Armenians (i.e. Karabakh) to Azerbaijan - Turkey's strategic partner. It should be noted that it was due to "brotherly affections" that Turkey closed the border with Armenia in 1993 and since then there have been no diplomatic relations between these two neighbors.

Russia's role is also very ambiguous in this situation. By starting the war with Georgia it gave Turkey an opportunity to grab the right moment and try to re-establish relations with Armenia, especially when the bridges in Georgia leading to Armenia were bombed and destroyed. During the Russian-Georgian war Armenia happened to appear in a blockade - closed borders with neighboring Turkey and Azerbaijan, a bombed bridge in Georgia - the only terrestrial link to transport goods to Armenia, especially excise goods - petrol, oil, alcohol, etc., which is not possible to do from Iran.

The establishment of the Alliance also pursues another important idea for the countries of the Caucasus - its existence is believed to loosen Russia's grip in the region and give more "independence" to their governments. If Georgia and Turkey may easily agree on the notion, it still remains a disputable issue for Armenia and Azerbaijan, as there exists the unsettled conflict of Nagorno-Karabakh. Despite being members of the OSCE and despite the efforts taken by the Minsk group over the frozen conflict, Armenia believes that it is Russia that hinders Azerbaijan from taking decisive steps towards armed conflict.

Being Armenia's "seeming" supporter, Moscow unofficially supported Baku's and Ankara's initiatives towards the failure of the ratification of the protocols signed in Zurich in October 2009. Armenia has always declared that it is ready to establish official diplomatic relations with Ankara without any preconditions, whereas the latter has stated that it will never ratify the protocols unless the Nagorno-Karabakh conflict is settled. By saying settled, Ankara, of course, means in favor of Azerbaijan. It once more proves that the recent pressures on Ankara by Baku were another political game conducted either with the hidden support of Russia and the States or without. Both ways they have their logical explanations bursting out from personal profit.

According to the protocols "on the establishment of diplomatic relations" and "on the development of bilateral relations" signed on October 10, 2009, there should have been steps taken in January 2010. Despite Armenia's readiness to establish diplomatic relations with Turkey and re-open the common closed border, the President had to call back the ratification of the protocols from the agenda of the Armenian Parliament on April 22, 2010 right after his return from the States and two days before the $95^{\text {th }}$ anniversary of the Armenian Genocide executed in the Ottoman Empire in 1915, since no move forward was tracked from Turkey.

The American presence seems to be softened in the region, and taking up the opportunity, Azerbaijan, strengthening its relations with Iran, Russia and Turkey strives for "kicking out" the US from the field.

Thus, in the case of Turkey gaining strengthened positions over the region, the EU will use the opportunity of conducting entrance negotiations with Turkey and 
take up the privilege of "reigning" over the Caucasus. This even leads Turkish political experts and think-tanks to express the opinion that if Turkey resigned from the Atlantic Treaty and gave up its EU aspirations, the country's position in the motherland would be stronger from all viewpoints than in the current situation, when due to Turkey's efforts Europe and America are competing over the region.

\section{NETOGRAPHY}

Accession of Turkey to the European Union, http://en.wikipedia.org/wiki/Accession_of_Turkey_to_ the_European_Union, retrieved: 02.04.2010.

EUobserver, No one can leave the euro, http:/ / euobserver.com/9/113563, retrieved: 8. 08. 2011.

European Council in Copenhagen, June 21-22, 1993, Conclusions of the Presidency, http://www.europarl. europa.eu/summits/copenhagen/co_en.pdf, retrieved: 26. 10. 2011.

Reiermann C. (2011), Greece out of the EU? Germany says yes, Greece says no and claims German conspiracy?, http://collapserpg.blogspot.com/2011/05/greece-out-of-eu.html, retrieved: 07.05.2011.

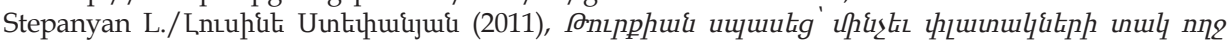

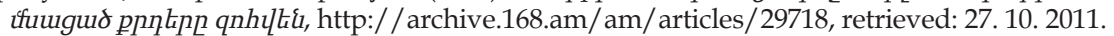

World StatInfo, http:/ / www.worldometers.info, retrieved: 25.10.2011. 